\title{
Article
}

\section{Stibiogoldfieldite, $\mathrm{Cu}_{12}\left(\mathrm{Sb}_{2} \mathrm{Te}_{2}\right) \mathrm{S}_{13}$, a new tetrahedrite-group mineral}

\author{
Cristian Biagioni ${ }^{1}$, Jiři Sejkora ${ }^{2}$ (D), Silvia Musetti ${ }^{\star \star}$, Emil Makovicky ${ }^{3}$, Renato Pagano ${ }^{4}$, Marco Pasero ${ }^{1}$ \\ and Zdeněk Dolníček² \\ ${ }^{1}$ Dipartimento di Scienze della Terra, Università di Pisa, Via Santa Maria 53, 56126 Pisa, Italy; ${ }^{2}$ Department of Mineralogy and Petrology, National Museum, Cirkusová \\ 1740, 193 00, Praha 9, Czech Republic; ${ }^{3}$ Department of Geoscience and Resource Management, University of Copenaghen, Østervoldgade 10, DK-1350, Copenhagen \\ K, Denmark; and ${ }^{4}$ Via San Francesco d'Assisi, 30, I-20092 Cinisello Balsamo (Mi), Italy
}

\begin{abstract}
Stibiogoldfieldite, $\mathrm{Cu}_{12}\left(\mathrm{Sb}_{2} \mathrm{Te}_{2}\right) \mathrm{S}_{13}$, was approved as a new mineral species from the Mohawk mine, Goldfield mining district, Esmeralda County, Nevada, USA. It occurs as metallic anhedral grains, dark grey in colour. It is associated with quartz, pyrite and an $\mathrm{Ag}-\mathrm{Bi}-(\mathrm{S}, \mathrm{Se})$ phase (holotype material) and with quartz, pyrite, calaverite, bismuthinite, bohdanowiczite, and the Ag-Bi-(S,Se) phase (cotype material). In reflected light, stibiogoldfieldite is isotropic, grey in colour, with indistinct brownish shade. Reflectance data in air $[R(\%)]$ are: 31.1 at $470 \mathrm{~nm}, 30.9$ at $546 \mathrm{~nm}, 30.8$ at $589 \mathrm{~nm}$ and 31.0 at $650 \mathrm{~nm}$. Electron microprobe analysis for holotype material gave (in wt.\% average of 60 spot analyses): $\mathrm{Cu} 45.03(60), \mathrm{Ag} 0.26(7), \mathrm{Fe} \mathrm{0.02(3),} \mathrm{Zn} \mathrm{0.13(15),} \mathrm{Sn} \mathrm{0.02(4),} \mathrm{Pb} \mathrm{0.05(6),} \mathrm{Sb} \mathrm{8.02(62),} \mathrm{As} \mathrm{2.80(65),} \mathrm{Bi} \mathrm{2.77}$ (87), Te 15.15(1.24), S 24.50(32), Se 0.52(11), total 99.27(69). On the basis of (As $+\mathrm{Sb}+\mathrm{Te}+\mathrm{Bi})=4$ atoms per formula unit (apfu), the empirical formula of stibiogoldfieldite is $\left(\mathrm{Cu}_{12.05} \mathrm{Ag}_{0.04} \mathrm{Zn}_{0.03} \mathrm{Fe}_{0.01}\right)_{\Sigma 12.13}\left(\mathrm{Sb}_{1.12} \mathrm{As}_{0.63} \mathrm{Bi}_{0.23} \mathrm{Te}_{2.02}\right)_{\Sigma 4.00}\left(\mathrm{~S}_{12.99} \mathrm{Se}_{0.11}\right)_{\Sigma 13.10}$. Chemical data on an additional sample from the same locality (cotype material) gave the following results (in wt.\% - average of 181 spot analyses): Cu 43.84(63), Ag 0.21(7), Sb 5.92(78), As 2.63(45), Te 20.07(1.19), S 25.13(53), Se 0.97(35), total 99.47(66). On the basis of (As + Sb + $\mathrm{Te}+\mathrm{Bi})=4$ apfu, the empirical formula of cotype material is $\left(\mathrm{Cu}_{11.30} \mathrm{Ag}_{0.03}\right)_{\Sigma 11.33}\left(\mathrm{Sb}_{0.80} \mathrm{As}_{0.57} \mathrm{Bi}_{0.06} \mathrm{Te}_{2.57}\right)_{\Sigma 4.00}\left(\mathrm{~S}_{12.83} \mathrm{Se}_{0.20}\right)_{\Sigma 13.03}$. Stibiogoldfieldite is cubic, $\bar{I} \overline{4} 3 \mathrm{~m}$, with unit-cell parameters $a=10.3466(17) \AA, V=1107.6(5) \AA^{3}$ and $Z=2$ (holotype). Unit-cell parameters for the cotype sample are $a=10.3035(2) \AA$ and $V=1093.83(7) \AA^{3}$. The crystal structure of holotype stibiogoldfieldite was refined by single-crystal X-ray diffraction data to a final $R_{1}=0.032$ on the basis of 285 reflections with $F_{\mathrm{o}}>4 \sigma\left(F_{\mathrm{o}}\right)$ and 20 refined parameters. Stibiogoldfieldite is isotypic with other members of the tetrahedrite group.
\end{abstract}

Keywords: stibiogoldfieldite, new mineral, sulfosalt, copper, antimony, tellurium, crystal structure, Goldfield mining district, Nevada, USA

(Received 3 November 2021; accepted 29 December 2021; Accepted Manuscript published online: 7 January 2022; Associate Editor: František Laufek)

\section{Introduction}

The tetrahedrite group includes the most common sulfosalts occurring in hydrothermal ore deposits, where they host different elements owing to the possibility of several homo- and heterovalent substitutions (Moëlo et al., 2008; Biagioni et al., 2020). This compositional diversity is reflected in the relatively large number of mineral species belonging to this group that have been approved by the Commission on New Minerals, Nomenclature and Classification of the International Mineralogical Association (IMA-CNMNC). In addition to the 11 mineral species redefined in Biagioni et al. (2020), a total of 32 potential end-member compositions has been hypothesised in the tetrahedrite group based on the literature. Since the publication of the tetrahedrite-group nomenclature, 13 new mineral

${ }^{\star}$ Author for correspondence: Silvia Musetti, Email: silvia.musetti@phd.unipi.it Cite this article: Biagioni C., Sejkora J., Musetti S., Makovicky E., Pagano R., Pasero M. and Dolníček Z. (2022) Stibiogoldfieldite, $\mathrm{Cu}_{12}\left(\mathrm{Sb}_{2} \mathrm{Te}_{2}\right) \mathrm{S}_{13}$, a new tetrahedrite-group mineral. Mineralogical Magazine 86, 168-175. https://doi.org/10.1180/mgm.2021.107 species have been described, emphasising the chemical variability of this isotypic group.

Among the chemical constituents hosted in tetrahedrite-group minerals and representing species-forming elements, the rarest is Te $(Z=52)$, with an estimated crustal abundance of $5 \mathrm{ng} / \mathrm{g}$ (e.g. Wedepohl, 1995). Its occurrence in this sulfosalt group has been known since the first description of goldfieldite (Sharwood, 1907; Ransome, 1909), though only Thompson (1946) proved it had isotypic relations with tetrahedrite. The actual definition of goldfieldite has been debated by several authors (e.g. Trudu and Knittel, 1998, and references therein) and it was finally solved by Biagioni et al. (2020) taking into account the current IMA-CNMNC guidelines and in agreement with the Report of the Sulfosalt Sub-Committee (Moëlo et al., 2008). Goldfieldite is defined as the Te-rich member of the tetrahedrite group having end-member formula $\left(\mathrm{Cu}_{4} \square_{2}\right) \mathrm{Cu}_{6} \mathrm{Te}_{4} \mathrm{~S}_{13}$; its type locality is the Mohawk mine, Goldfield, Nevada, USA. In fact, chemical data available for samples from this locality show $(\mathrm{As}+\mathrm{Sb}+\mathrm{Bi}) / \mathrm{Te}$ atomic ratios close to 1 , with $\mathrm{Sb}>(\mathrm{As}, \mathrm{Bi})$, i.e. close to the end-member formula $\mathrm{Cu}_{12}\left(\mathrm{Sb}_{2} \mathrm{Te}_{2}\right) \mathrm{S}_{13}$

(C) The Author(s), 2022. Published by Cambridge University Press on behalf of The Mineralogical Society of Great Britain and Ireland. This is an Open Access article, distributed under the terms of the Creative Commons Attribution licence (http://creativecommons.org/licenses/by/4.0/), which permits unrestricted re-use, distribution and reproduction, provided the original article is properly cited. 

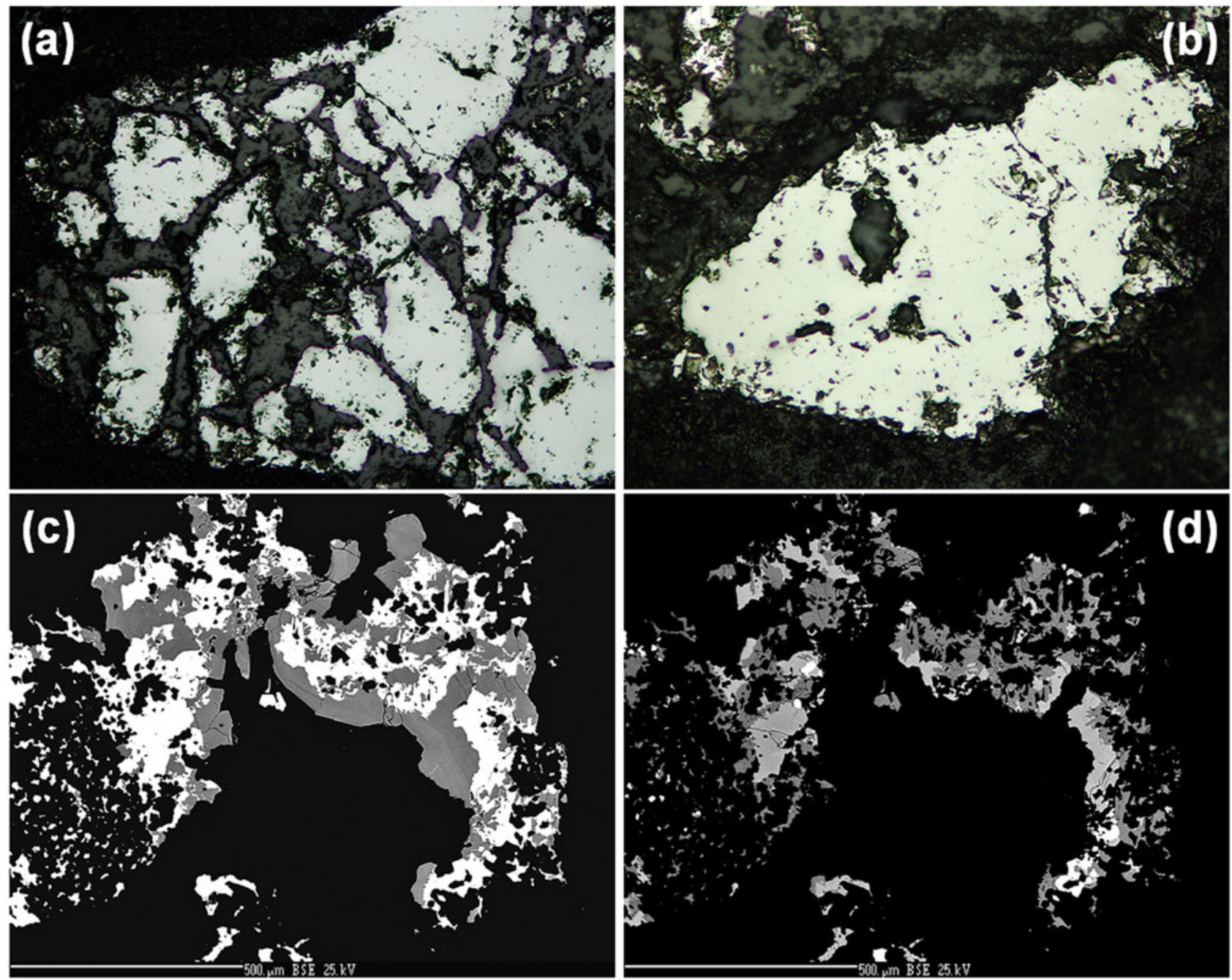

Fig. 1. (a, b) Holotype (sample P1P 78/2020) and (c, d) cotype (sample P1P 80/2020) specimens of stibiogoldfieldite. (a, b) Reflected light images (one polar) of holotype stibiogoldfieldite, as anhedral grains up to $0.6 \mathrm{~mm}$ across in quartz. Field of view: $1.2 \mathrm{~mm}$ (a) and $0.6 \mathrm{~mm}$ (b). (c, d) BSE images showing stibiogoldfieldite [dark grey in (c)], as anhedral grains up to $0.3 \mathrm{~mm}$ in quartz gangue; white mineral phases in (c) are distinguished in (d), collected using different image conditions: gold (white), calaverite (grey), and an $\mathrm{Ag}-\mathrm{Bi}-(\mathrm{S}, \mathrm{Se})$ phase (dark grey).

(e.g. Ransome, 1909; Lévy, 1967). For this reason, Shimizu and Stanley (1991) applied the name goldfieldite to this composition. However, in order to avoid any confusion, the name goldfieldite is currently applied to the Te-pure compositional end-member, whereas a new name should be associated with the $\mathrm{Sb} / \mathrm{Te}$ and As/Te end-members (Biagioni et al., 2020).

During the examination of some specimens classified as goldfieldite from the Mohawk mine, the phase corresponding to the end-member $\mathrm{Cu}_{12}\left(\mathrm{Sb}_{2} \mathrm{Te}_{2}\right) \mathrm{S}_{13}$ was found and characterised. The new mineral and its name, stibiogoldfieldite (in agreement with Biagioni et al., 2020), have been approved by the IMA-CNMNC (IMA2020-104, Biagioni et al., 2021). Type material is deposited in the mineralogical collections of the Museo di Storia Naturale of the University di Pisa, Via Roma 79, Calci, Pisa, Italy, under catalogue number 19926 (part of holotype), and of the Department of Mineralogy and Petrology, National Museum, Cirkusová 1740, Prague, Czech Republic, under catalogue numbers P1P 78/2020 (part of holotype) and P1P 80/ 2020 (cotype). In addition, a sample labelled 'goldfieldite' from the Prasolovskoe Au deposit, Kuril Islands, Sakhalin Oblast, Russia, belonging to the private collection of one of the authors (RP catalogue number 8947) was examined and chemically characterised.
In this paper the description of the new member of the tetrahedrite group stibiogoldfieldite is reported and new crystal chemical data on Te-bearing members of this sulfosalt group are discussed.

\section{Occurrence and physical properties}

Stibiogoldfieldite was found at the Mohawk mine $\left(37^{\circ} 43^{\prime} 01^{\prime \prime} \mathrm{N}\right.$, $\left.117^{\circ} 13^{\prime} 25^{\prime \prime} \mathrm{W}\right)$, Goldfield mining district, Esmeralda County, Nevada, USA. The Goldfield mining district belongs to a series of large epithermal precious metal ore deposits hosted in Oligocene-to-Miocene hydrothermally altered volcanic rocks, in the western part of the Basin and Range province (Ashley, 1974), and structurally controlled by a caldera formed during the early stage of the volcanic activity. Further details can be found in Rockwell (2000) and references therein.

Stibiogoldfieldite forms anhedral grains (Fig. 1), up to $0.6 \mathrm{~mm}$ in size, dark grey in colour, with grey streak and metallic lustre. Mohs hardness was not measured, owing to the small size of the grain studied, but it should be close to $3 \frac{1}{2}-4$, in agreement with other members of the tetrahedrite group. Stibiogoldfieldite 
Table 1. Reflectance data for holotype stibiogoldfieldite.

\begin{tabular}{lccc}
\hline$\lambda(\mathrm{nm})$ & $R(\%)$ & $\lambda(\mathrm{nm})$ & $R(\%)$ \\
\hline 400 & 31.6 & 560 & 30.9 \\
420 & 31.6 & 580 & 30.9 \\
440 & 31.6 & $\mathbf{5 8 9}$ & 30.8 \\
460 & 31.3 & 600 & 30.9 \\
$\mathbf{4 7 0}$ & $\mathbf{3 1 . 1}$ & 620 & 30.9 \\
480 & 31.1 & 640 & 31.0 \\
500 & 31.1 & $\mathbf{6 5 0}$ & $\mathbf{3 1 . 0}$ \\
520 & 31.0 & 660 & 31.0 \\
540 & 30.9 & 680 & 31.0 \\
$\mathbf{5 4 6}$ & $\mathbf{3 0 . 9}$ & 700 & 31.0 \\
\hline
\end{tabular}

The reference wavelengths required by the Commission on Ore Mineralogy (COM) are given in bold.

is brittle, with a conchoidal fracture and an indistinct cleavage. Due to the small size of the grains studied, density was not measured; on the basis of the empirical formula and the single-crystal $\mathrm{X}$-ray diffraction data, the calculated density is $5.055 \mathrm{~g} \cdot \mathrm{cm}^{-3}$.

In reflected light, stibiogoldfieldite is isotropic. It is grey, with indistinct brownish shade. Internal reflections were not observed. Reflectance values measured in air on the holotype sample using a spectrophotometer MSP400 Tidas at Leica microscope, with a $50 \times$ objective, are given in Table 1 and shown in Fig. 2.

Stibiogoldfieldite was identified in a quartz sample, in association with pyrite and an $\mathrm{Ag}-\mathrm{Bi}-(\mathrm{S}, \mathrm{Se})$ phase (holotype material Fig. 1). Another specimen of stibiogoldfieldite was later determined from the same kind of occurrence; in this sample (Fig. 1) it forms anhedral grains, associated with pyrite, calaverite, bismuthinite, bohdanowiczite and the Ag-Bi-(S,Se) phase (cotype material). Some $\mu \mathrm{m}$-sized domains of the sample studied have $\mathrm{As}>\mathrm{Sb}$, thus corresponding to the not yet approved mineral 'arsenogoldfieldite'. According to Tolman and Ambrose (1934), the occurrence of stibiogoldfieldite at the Mohawk mine may be related to the circulation of Te-bearing hydrothermal fluids during the late-stage evolution of the Goldfield ore deposits.

The sample labelled as 'goldfieldite' from the Prasolovskoe $\mathrm{Au}$ deposit was represented by black anhedral grains. Some data about this ore deposit and its tetrahedrite-group minerals can be found in Kovalenker et al. (1989), Kovalenker and Plotinskaya (2005) and Kemkina (2007).

\section{Chemical data}

Quantitative chemical analyses were carried out using a Cameca SX 100 electron microprobe (National Museum of Prague, Czech Republic) and the following experimental conditions: wavelength dispersive spectroscopy mode, accelerating voltage $25 \mathrm{kV}$, beam current $20 \mathrm{nA}$ and beam diameter $1 \mu \mathrm{m}$. Standards (element, emission line) were: chalcopyrite $(\mathrm{CuK \alpha}$ and $\mathrm{SK \alpha})$, pyrite $(\mathrm{FeK} \alpha)$, ZnS ( $\mathrm{ZnK \alpha}$ ), NiAs (AsL $\beta)$, Ag metal (AgL $\alpha)$, Sn $(\mathrm{Sn} L \alpha), \mathrm{Sb}_{2} \mathrm{~S}_{3}(\mathrm{Sb} L \alpha), \mathrm{PbTe}(\mathrm{Te} M \alpha), \mathrm{Tl}(\mathrm{Br}, \mathrm{I})$ (Tl $\left.L \alpha\right), \mathrm{PbS}$ $(\mathrm{PbM} \alpha), \mathrm{Bi}_{2} \mathrm{Se}_{3}(\mathrm{Bi} M \beta)$ and $\mathrm{PbSe}(\mathrm{Se} L \beta)$. The amount of other elements with $Z>8$ was below detection limits. Matrix correction by PAP procedure (Pouchou and Pichoir, 1985) was applied to the data. Results (average of 60 and 181 spot analyses for holotype and cotype samples, respectively) are given in Table 2 .

The empirical formula of stibiogoldfieldite from the Mohawk mine, recalculated on the basis of $(\mathrm{As}+\mathrm{Sb}+\mathrm{Bi}+\mathrm{Te})=4$ atoms per formula unit (apfu), is $\left(\mathrm{Cu}_{12.05(15)} \mathrm{Ag}_{0.04(1)} \mathrm{Zn}_{0.03(4)} \mathrm{Fe}_{0.01(1)}\right)_{\Sigma 12.13}$ $\left(\mathrm{Sb}_{1.12(8)} \mathrm{As}_{0.63(14)} \mathrm{Bi}_{0.23(7)} \mathrm{Te}_{2.02(17)}\right)_{\Sigma 4.00}\left(\mathrm{~S}_{12.99(20)} \mathrm{Se}_{0.11(2)}\right)_{\Sigma 13.10}$

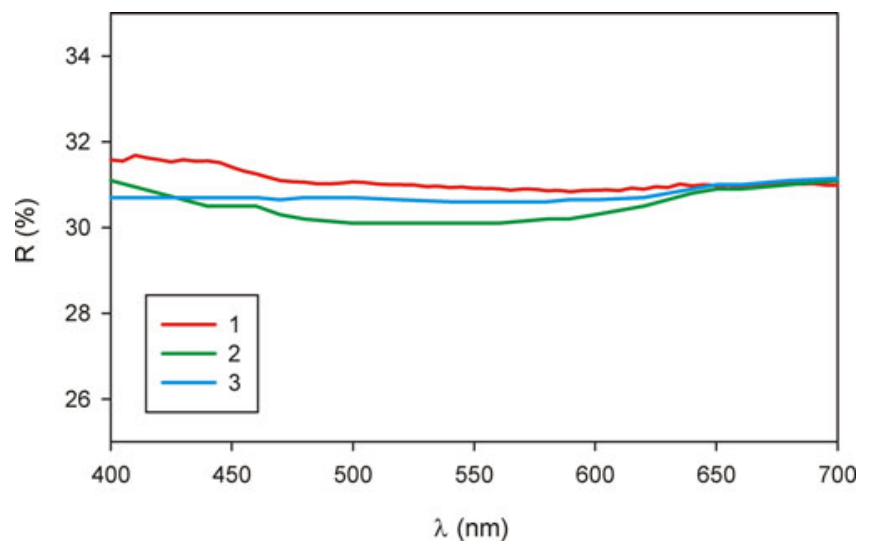

Fig. 2. Reflectance curves for stibiogoldfieldite (1) from the Mohawk mine (holotype sample) measured in air. For comparison, the reflectance curves of stibiogoldfieldite (2) from Goldfield (Criddle and Stanley, 1993), and 'arsenogoldfieldite' (3) from the Tramway mine (Criddle and Stanley, 1993) are shown. Both samples were described as 'goldfieldite' by Criddle and Stanley (1993).

(holotype) and $\left(\mathrm{Cu}_{11.30(22)} \mathrm{Ag}_{0.03(1)}\right)_{\Sigma 11.33}\left(\mathrm{Sb}_{0.80(11)} \mathrm{As}_{0.57(10)} \mathrm{Bi}_{0.06(3)}\right.$ $\left.\mathrm{Te}_{2.57(14)}\right)_{\Sigma 4.00}\left(\mathrm{~S}_{12.83(29)} \mathrm{Se}_{0.20(7)}\right)_{\Sigma 13.03}$ (cotype). Associated 'arsenogoldfieldite', observed in cotype material, has the chemical formula $\left(\mathrm{Cu}_{11.39(33)} \mathrm{Ag}_{0.04(1)}\right)_{\Sigma 11.43}\left(\mathrm{As}_{0.93(32)} \mathrm{Sb}_{0.56(20)}\right.$ $\left.\mathrm{Bi}_{0.04(2)} \mathrm{Te}_{2.47(22)}\right)_{\Sigma 4.00}\left(\mathrm{~S}_{12.90(27)} \mathrm{Se}_{0.16(4)}\right)_{\Sigma 13.06}$.

The end-member formula of stibiogoldfieldite is $\mathrm{Cu}_{12}\left(\mathrm{Sb}_{2} \mathrm{Te}_{2}\right)$ $\mathrm{S}_{13}(Z=2)$, corresponding to (in wt.\%) $\mathrm{Cu} 45.44, \mathrm{Sb} 14.51, \mathrm{Te}$ 15.21, S 24.84, total 100.00 .

Chemical data of the sample from the Prasolovskoe Au deposit and those of 'arsenogoldfieldite' observed in the cotype sample, along with all spot analyses performed on holotype and cotype material, are deposited as Supplementary Table S1 (see below).

\section{X-ray crystallography}

Single-crystal X-ray diffraction intensity data were collected on the holotype stibiogoldfieldite using a Bruker Smart Breeze diffractometer $(50 \mathrm{kV}$ and $30 \mathrm{~mA})$ equipped with a Photon II CCD detector and graphite-monochromatised MoKo radiation (Dipartimento di Scienze della Terra, Università di Pisa, Italy). The detector-to-crystal distance was set at $50 \mathrm{~mm}$. Data were collected using $\varphi$ scan mode in $0.5^{\circ}$ slices, with an exposure time of $10 \mathrm{~s}$ per frame, and they were corrected for Lorentz, polarisation, absorption and background effects using the software package Apex3 (Bruker AXS Inc., 2016). The refined unit-cell parameters are $a=10.3466(17) \AA, V=1107.6(5) \AA^{3}$; and space group $I \overline{4} 3 m$. The crystal structure of stibiogoldfieldite was refined using Shelxl-2018 (Sheldrick, 2015) starting from the structural model of Johnson and Burnham (1985). The following neutral scattering curves, taken from the International Tables for Crystallography (Wilson, 1992), were used: $\mathrm{Cu} v$ s. $\square$ at the $M(2)$ and $M(1)$ sites, Te vs. As at $X(3)$, and $\mathrm{S}$ at $\mathrm{S}(1)$ and $\mathrm{S}(2)$ sites. After several cycles of isotropic refinement, the agreement factor $R_{1}$ converged to 0.0755 , confirming the correctness of the structural model. The occurrence of racemic twinning was taken into account and the absolute structure needed to be inverted. The $M(2)$ and $M(1)$ sites were found to be fully occupied by $\mathrm{Cu}$, and thus their site occupancy factors (s.o.f.) were fixed to 1 . The anisotropic structural model for all atoms converged to $R_{1}=0.0316$ for 285 unique reflections with $F_{\mathrm{o}}>4 \sigma\left(F_{\mathrm{o}}\right)(0.0485$ for all the 331 measured unique reflections) and 20 refined parameters. Table 3 gives details of data collection and refinement. 
Table 2. Chemical data for stibiogoldfieldite.

\begin{tabular}{|c|c|c|c|c|c|c|}
\hline \multirow[b]{3}{*}{ Constituent } & \multicolumn{3}{|c|}{ Holotype sample } & & \multirow{3}{*}{$\begin{array}{l}\text { Cotype sample } \\
\qquad \begin{array}{c}(n=181) \\
\text { Range }\end{array}\end{array}$} & \multirow[b]{3}{*}{ e.s.d. } \\
\hline & \multicolumn{3}{|c|}{$(n=60)$} & & & \\
\hline & & Range & e.s.d. & & & \\
\hline \multicolumn{7}{|l|}{ wt.\% } \\
\hline $\mathrm{Cu}$ & 45.03 & $44.14-46.71$ & 0.60 & 43.84 & $42.53-45.84$ & 0.63 \\
\hline $\mathrm{Ag}$ & 0.26 & $0.09-0.38$ & 0.07 & 0.21 & $0.06-0.38$ & 0.07 \\
\hline $\mathrm{Fe}$ & 0.02 & $0.00-0.13$ & 0.03 & - & - & - \\
\hline $\mathrm{Zn}$ & 0.13 & $0.00-0.47$ & 0.15 & - & - & - \\
\hline Sn & 0.02 & $0.00-0.20$ & 0.04 & - & - & - \\
\hline $\mathrm{Pb}$ & 0.05 & $0.00-0.18$ & 0.06 & - & - & - \\
\hline $\mathrm{Sb}$ & 8.02 & $6.21-9.12$ & 0.62 & 5.92 & $4.16-7.82$ & 0.78 \\
\hline As & 2.80 & $1.75-4.16$ & 0.65 & 2.63 & $1.27-3.72$ & 0.45 \\
\hline $\mathrm{Bi}$ & 2.77 & $0.86-4.65$ & 0.87 & 0.70 & $0.18-1.58$ & 0.35 \\
\hline Te & 15.15 & $13.51-19.31$ & 1.24 & 20.07 & $16.81-22.73$ & 1.19 \\
\hline$S$ & 24.50 & $23.85-25.34$ & 0.32 & 25.13 & $23.99-26.60$ & 0.53 \\
\hline Se & 0.52 & $0.33-0.77$ & 0.11 & 0.97 & $0.27-2.06$ & 0.35 \\
\hline Total & 99.27 & $98.04-100.80$ & 0.69 & 99.47 & $98.50-101.67$ & 0.66 \\
\hline \multicolumn{7}{|c|}{ Atoms per formula unit on the basis of $\mathrm{As}+\mathrm{Bi}+\mathrm{Sb}=4$} \\
\hline $\mathrm{Cu}$ & 12.05 & $11.61-12.29$ & 0.15 & 11.30 & $10.83-11.99$ & 0.22 \\
\hline $\mathrm{Ag}$ & 0.04 & $0.01-0.06$ & 0.01 & 0.03 & $0.01-0.06$ & 0.01 \\
\hline $\mathrm{Fe}$ & 0.01 & $0.00-0.04$ & 0.01 & - & - & - \\
\hline $\mathrm{Zn}$ & 0.03 & $0.00-0.12$ & 0.04 & - & - & - \\
\hline Sn & 0.00 & $0.00-0.03$ & 0.01 & - & - & - \\
\hline $\mathrm{Pb}$ & 0.00 & $0.00-0.02$ & 0.00 & - & - & - \\
\hline $\mathrm{Sb}$ & 1.12 & $0.85-1.27$ & 0.08 & 0.80 & $0.56-1.06$ & 0.11 \\
\hline As & 0.63 & $0.40-0.91$ & 0.14 & 0.57 & $0.28-0.81$ & 0.10 \\
\hline $\mathrm{Bi}$ & 0.23 & $0.07-0.38$ & 0.07 & 0.06 & $0.01-0.12$ & 0.03 \\
\hline $\mathrm{Te}$ & 2.02 & $1.80-2.53$ & 0.17 & 2.57 & $2.21-2.86$ & 0.14 \\
\hline$S$ & 12.99 & $12.55-13.46$ & 0.20 & 12.83 & $12.16-13.54$ & 0.29 \\
\hline $\mathrm{Se}$ & 0.11 & $0.07-0.17$ & 0.02 & 0.20 & $0.06-0.43$ & 0.07 \\
\hline$E v(\%)^{\star}$ & +0.07 & $-2.54-2.02$ & 1.11 & -0.52 & $-5.16-4.01$ & 1.83 \\
\hline
\end{tabular}

'-'= below detection; ${ }^{*} E v(\%)=[\Sigma(\mathrm{val}+)-\Sigma($ val- $)] \times 100 / \Sigma($ val- $)$.

Table 3. Summary of crystal data and parameters describing data collection and refinement for stibiogoldfieldite.

\begin{tabular}{|c|c|}
\hline \multicolumn{2}{|l|}{ Crystal data } \\
\hline Crystal size (mm) & $0.100 \times 0.080 \times 0.075$ \\
\hline Cell setting, space group & Cubic, $1 \overline{4} 3 m$ \\
\hline$a(\AA)$ & $10.3466(17)$ \\
\hline$V\left(\AA^{3}\right)$ & $1107.6(5)$ \\
\hline$Z$ & 2 \\
\hline \multicolumn{2}{|l|}{ Data collection } \\
\hline Radiation, wavelength $(\AA)$ & MoK $\alpha, \lambda=0.71073$ \\
\hline Temperature $(\mathrm{K})$ & 293 \\
\hline $2 \theta_{\max }\left({ }^{\circ}\right)$ & 65.49 \\
\hline Measured reflections & 1562 \\
\hline Unique reflections & 331 \\
\hline Reflections with $F_{\mathrm{o}}>4 \sigma\left(F_{\mathrm{o}}\right)$ & 285 \\
\hline$R_{\text {int }}$ & 0.0391 \\
\hline$R \sigma$ & 0.0400 \\
\hline Range of $h, k, l$ & $-11 \leq h \leq 12,-14 \leq k \leq 9,-9 \leq l \leq 15$ \\
\hline \multicolumn{2}{|l|}{ Refinement } \\
\hline$R\left[F_{\mathrm{o}}>4 \sigma\left(F_{\mathrm{o}}\right)\right]$ & 0.0316 \\
\hline$R$ (all data) & 0.0485 \\
\hline$w R\left(\text { on } F_{\mathrm{o}}^{2}\right)^{1}$ & 0.0715 \\
\hline Gof & 1.124 \\
\hline Absolute structure parameter ${ }^{2}$ & $-0.05(9)$ \\
\hline Number of least-squares parameters & 20 \\
\hline \multirow[t]{2}{*}{$\Delta \rho_{\max }, \Delta \rho_{\min }\left(e^{-} \AA^{-3}\right)$} & $+1.51[$ at $0.30 \AA$ from $X(3)]$ \\
\hline & -1.57 [at $0.80 \AA$ from $X(3)$ ] \\
\hline
\end{tabular}

${ }^{1} \mathrm{w}=1 /\left[\sigma^{2}\left(F_{\mathrm{o}}^{2}\right)+18.1789 P\right]$, where $P=\left(F_{\mathrm{o}}^{2}+2 F_{\mathrm{c}}^{2}\right) / 3$

${ }^{2}$ Flack (1983)

Powder X-ray diffraction (PXRD) data of holotype stibiogoldfieldite were collected using a $114.6 \mathrm{~mm}$ Gandolfi camera and Ni-filtered $\mathrm{CuK \alpha}$ radiation (Dipartimento di Scienze della Terra,
Table 4. Powder X-ray diffraction data for holotype and cotype samples of stibiogoldfieldite.*

\begin{tabular}{|c|c|c|c|c|c|c|c|}
\hline \multicolumn{4}{|c|}{ Holotype } & \multicolumn{4}{|c|}{ Cotype } \\
\hline Iobs & $d_{\mathrm{obs}}$ & $I_{\text {calc }}$ & $d_{\text {calc }}$ & $h k l$ & $I_{\text {obs }}$ & $d_{\text {obs }}$ & $d_{\text {calc }}$ \\
\hline - & - & 1.0 & 7.3162 & 110 & & & \\
\hline - & - & 3.4 & 5.1733 & 200 & 5.9 & 5.1524 & 5.1517 \\
\hline vw & 4.23 & 2.2 & 4.2240 & 211 & 4.5 & 4.2054 & 4.2064 \\
\hline $\mathbf{m w}$ & 3.669 & 9.1 & 3.6581 & 220 & 18.9 & 3.6442 & 3.6428 \\
\hline vs & 2.987 & 100.0 & 2.9868 & 222 & 100.0 & 2.9743 & 2.9744 \\
\hline w & 2.767 & 5.3 & 2.7653 & 321 & 7.6 & 2.7537 & 2.7537 \\
\hline m & 2.598 & 24.4 & 2.5867 & 400 & 18.8 & 2.5762 & 2.5759 \\
\hline \multirow[t]{2}{*}{$\mathrm{mw}$} & 2.450 & 5.3 & 2.4387 & 411 & 7.1 & 2.4289 & 2.4286 \\
\hline & & 1.8 & 2.4387 & 330 & & & 2.4286 \\
\hline w & 2.312 & 2.9 & 2.3136 & 420 & 6.1 & 2.3039 & 2.3039 \\
\hline w & 2.205 & 2.4 & 2.2059 & 332 & 1.9 & 2.1962 & 2.1967 \\
\hline w & 2.115 & 2.2 & 2.1120 & 422 & 5.6 & 2.1031 & 2.1032 \\
\hline \multirow[t]{2}{*}{$\mathrm{mw}$} & 2.036 & 3.7 & 2.0291 & 431 & 10.2 & 2.0204 & 2.0207 \\
\hline & & 2.7 & 2.0291 & 510 & & & 2.0207 \\
\hline $\mathrm{mw}$ & 1.897 & 6.0 & 1.8890 & 521 & 4.8 & 1.8813 & 1.8812 \\
\hline $\mathbf{s}$ & 1.833 & 50.8 & 1.8290 & 440 & 31.7 & 1.8215 & 1.8214 \\
\hline vw & 1.780 & 1.7 & 1.7744 & 433 & 1.4 & 1.7672 & 1.7670 \\
\hline vw & 1.732 & 1.3 & 1.7244 & 442 & 2.0 & 1.7175 & 1.7172 \\
\hline w & 1.682 & 4.9 & 1.6784 & 611 & 3.6 & 1.6715 & 1.6714 \\
\hline w & 1.640 & 2.5 & 1.6359 & 620 & 2.2 & 1.6291 & 1.6291 \\
\hline vw & 1.598 & 1.4 & 1.5965 & 541 & - & - & \\
\hline ms & 1.564 & 31.9 & 1.5598 & 622 & 13.0 & 1.5534 & 1.5533 \\
\hline vw & 1.528 & 1.3 & 1.5255 & 631 & 0.4 & 1.5189 & 1.5192 \\
\hline w & 1.493 & 4.5 & 1.4934 & 444 & 1.9 & 1.4871 & 1.4872 \\
\hline \multirow[t]{4}{*}{ w } & 1.466 & 1.4 & 1.4632 & 543 & 1.3 & 1.4571 & 1.4571 \\
\hline & & 1.3 & 1.4632 & 550 & & & 1.4571 \\
\hline & & 1.0 & 1.4080 & 633 & 0.6 & 1.4020 & 1.4021 \\
\hline & & 1.5 & 1.3826 & 642 & 2.0 & 1.3770 & 1.3769 \\
\hline
\end{tabular}

*Intensity and $d_{\mathrm{hkl}}$ were calculated using the software PowderCell2.4 (Kraus and Nolze, 1996) on the basis of the structural model given in Table 5. Only reflections with $I_{\text {calc }}>1$ are listed. The five strongest reflections are given in bold. For the holotype sample, $I_{\text {obs }}$ were visually estimated. $\mathrm{vs}$. = very strong; $\mathrm{s}=$ strong; $\mathrm{ms}=$ medium-strong; $\mathrm{m}=$ medium; $\mathrm{mw}=$ mediumweak; $\mathrm{w}=$ weak; and $\mathrm{vw}=$ very weak.

Università di Pisa, Italy) owing to the paucity of material. Unit-cell parameters were refined on the basis of 18 unequivocally indexed reflections using UnitCell (Holland and Redfern, 1997) and are $a=10.3664(5) \AA$ and $V=1113.98(17) \AA^{3}$. The cotype sample was analysed at room temperature using a Bruker D8 Advance diffractometer equipped with a solid-state LynxEye detector and secondary monochromator producing $\mathrm{CuK \alpha}$ radiation at the Department of Mineralogy and Petrology, National Museum, Prague, Czech Republic. The instrument was operating at $40 \mathrm{kV}$ and $40 \mathrm{~mA}$. In order to minimise the background, the powder sample was placed on the surface of a flat $\mathrm{Si}$ wafer. The PXRD pattern was collected in Bragg-Brentano geometry in the $2 \theta$ range $3-70^{\circ}$, with step of $0.01^{\circ}$ and counting time of $20 \mathrm{~s}$ per step (total duration of the experiment was $c a .30 \mathrm{~h}$ ). The positions and intensities of diffraction effects were found and refined using the Pearson VII profile-shape function of the ZDS program package (Ondruš, 1993). Unit-cell parameters were refined by the least-square program of Burnham (1962) and are $a=10.3035(2) \AA$ and $V=1093.83(7) \AA^{3}$. Table 4 reports the observed and calculated PXRD patterns.

\section{Results and discussions}

\section{Crystal structure description}

Fractional atomic coordinates and equivalent isotropic displacement parameters for stibiogoldfieldite are reported in Table 5, and selected bond distances in Table 6. The bond-valence sums (BVS) are given in Table 7 and were obtained using the bond- 
Table 5. Sites, Wyckoff positions, site occupancy factors (s.o.f.), fractional atom coordinates and equivalent isotropic displacement parameters $\left(\AA^{2}\right)$ for stibiogoldfieldite.

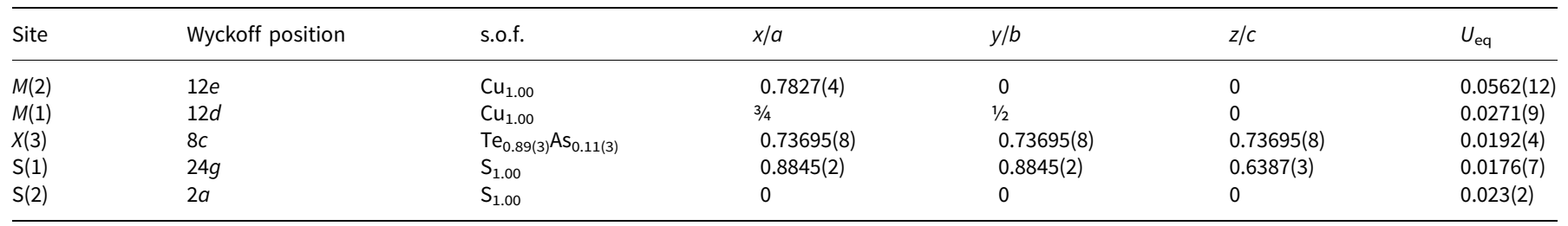

Table 6. Selected bond distances $(\AA ̊)$ for stibiogoldfieldite.

\begin{tabular}{llll}
\hline$M(1)-\mathrm{S}(1) \times 4$ & $2.3291(19)$ & $X(3)-\mathrm{S}(1) \times 3$ & $2.387(4)$ \\
$M(2)-\mathrm{S}(2)$ & $2.249(4)$ & & \\
$M(2)-\mathrm{S}(1) \times 2$ & $2.252(3)$ & & \\
\hline
\end{tabular}

Table 7. Weighted bond-valence sums (in valence units) for stibiogoldfieldite*.

\begin{tabular}{lccccc}
\hline Site & $M(1)$ & $M(2)$ & $X(3)$ & Lanions & Theoretical \\
\hline $\mathrm{S}(1)$ & $2 \times \rightarrow 0.28^{\times 4 \downarrow}$ & $0.35^{\times 2 \downarrow}$ & $1.13^{\times 3 \downarrow}$ & 2.04 & 2.00 \\
$\mathrm{~S}(2)$ & & 0.35 & & 2.10 & 2.00 \\
$\sum$ cations & 1.12 & 1.05 & 3.39 & & \\
Theoretical & 1.01 & 1.00 & 3.50 & &
\end{tabular}

*Left and right superscripts indicate the number of equivalent bonds (when $>1$ ) involving cations and anions, respectively. The following site occupancieswere used: $M(2)=$

$\mathrm{Cu}_{0.993} \mathrm{Ag}_{0.007} ; M(1)=\mathrm{Cu}_{0.993} \mathrm{Zn}_{0.005} \mathrm{Fe}_{0.002} ; X(3)=\mathrm{Sb}_{0.28} \mathrm{As}_{0.16} \mathrm{Bi}_{0.06} \mathrm{Te}_{0.50}$.

valence parameters of Brese and O'Keeffe (1991), assuming the simplified structural formula discussed below and neglecting minor Se. The crystallographic information files have been deposited with the Principal Editor of Mineralogical Magazine and are available as Supplementary material (see below).

Stibiogoldfieldite has isotypic relations with the other members of the tetrahedrite group; its crystal structure can be described as a collapsed sodalite-like framework of corner-sharing $M(1)$-centred tetrahedra with $\mathrm{S}(2)$-centred $M(2)$-octahedra and $X(3) \mathrm{S}(1)_{3}$ trigonal pyramids hosted within structural cages (e.g. Johnson et al., 1988).

The $M(2)$ site is three-fold coordinated and has a pure $\mathrm{Cu}$ occupancy, with only a negligible Ag content (0.04 apfu). Its average bond distance is $2.251 \AA$. Such a value can be compared with those shown by pure $\mathrm{Cu} M(2)$ sites in tetrahedrite $(2.259 \AA$ Wuensch, 1964) and tennantite $(2.240 \AA$ - Wuensch et al., $1966)$. The relatively large $U_{\text {eq }}$ value $\left(0.056 \AA^{2}\right)$ is probably related to the positional disorder usually associated to the $M(2)$ site (e.g. Andreasen et al., 2008; Welch et al., 2018). Such a disorder was not resolved in the refinement of the crystal structure of stibiogoldfieldite. The BVS at the $M(2)$ site (Table 7) is 1.05 valence units (vu), in agreement with the presence of monovalent cations. Its site population, based on electron microprobe and structural data, is proposed as ${ }^{M(2)}\left(\mathrm{Cu}_{5.96} \mathrm{Ag}_{0.04}\right)$, i.e. almost a pure $\mathrm{Cu}$ site.

The tetrahedrally coordinated $M(1)$ site is a pure $\mathrm{Cu}$ site, with only minor amounts of $\mathrm{Zn}$ and $\mathrm{Fe}$, i.e. ${ }^{M(1)}\left(\mathrm{Cu}_{5.96} \mathrm{Zn}_{0.03} \mathrm{Fe}_{0.01}\right)$. The average bond distance is $2.329 \AA$, to be compared with those observed in other $\mathrm{Cu}$-centred tetrahedrally coordinated sites, i.e. in chalcopyrite-like minerals (2.302-2.33 $\AA$; Hall, 1975). The BVS is $1.12 \mathrm{vu}$, agreeing with the dominance of $\mathrm{Cu}^{+}$at this structural site.

The $X(3)$ site has an average bond distance of $2.390 \AA$. Taking into account the electron microprobe data, the site occupancy $\left(\mathrm{Sb}_{0.28} \mathrm{As}_{0.16} \mathrm{Bi}_{0.06} \mathrm{Te}_{0.50}\right)$ can be proposed, which corresponds to a calculated mean atomic number (MAN) of 50.54 electrons, to be compared with the observed MAN of 49.98 electrons. Assuming idealised $X-S$ distances of $2.26,2.55,2.45$ and $2.34 \AA$ for $\mathrm{As}^{3+}, \mathrm{Bi}^{3+}, \mathrm{Sb}^{3+}$ and $\mathrm{Te}^{4+}$, respectively (calculated according to the bond parameters of Brese and O'Keeffe, 1991), an average $X(3)-S(1)$ distance of $2.37 \AA$ can be expected. The BVS is $3.39 \mathrm{vu}$, to be compared with a theoretical value of $3.50 \mathrm{vu}$.

The $S(1)$ site is four-fold coordinated and is bonded to two $M(1)$, one $M(2)$ and one $X(3)$. Its BVS is $2.04 \mathrm{vu}$. S(2) is octahedrally coordinated by atoms hosted at $M(2)$ sites, with BVS of $2.10 \mathrm{vu}$. Both S sites are fully occupied.

Coupling the results of the crystal structure refinement and the electron microprobe analysis, the structural formula of holotype stibiogoldfieldite can be written as ${ }^{M(2)}\left(\mathrm{Cu}_{5.96} \mathrm{Ag}_{0.04}\right)^{M(1)} \mathrm{Cu}_{6}{ }^{X(3)}$ $\left(\mathrm{Sb}_{0.28} \mathrm{As}_{0.16} \mathrm{Bi}_{0.06} \mathrm{Te}_{0.50}\right)_{4} \mathrm{~S}_{13}$.

\section{Crystal-chemistry of stibiogoldfieldite}

Tellurium-bearing tetrahedrite-group minerals display several crystal-chemical features that were deciphered towards the end of the 1960s. Kato and Sakurai (1970) and Kalbskopf (1974) realised that Te does not substitute for S (as initially hypothesised) but behaves like As and Sb, as proposed by Lévy (1967). This agrees with our results, showing a full $S$ occupancy at the $S(1)$ and $S(2)$ sites of stibiogoldfieldite and a site scattering at the $X(3)$ site in accord with a mixed (Sb,Te,As,Bi) occupancy.

Kalbskopf (1974) also reported the occurrence of vacancies at the trigonally-coordinated $M(2)$ sites in Te-rich tetrahedritegroup minerals. Similar results were then obtained by Dmitrieva et al. (1987) and Pohl et al. (1996). At the end of the 1970s and during the 1980s, several authors (e.g. Novgorodova et al., 1978; Kase, 1986; Knittel, 1989) proposed that the accommodation of $\mathrm{Te}^{4+}$ (up to $2 \mathrm{Te}$ apfu) in the crystal structure of tetrahedrite-group minerals is possible through an increase of the $(\mathrm{Cu}, \mathrm{Ag})^{+}$content from 10 to 12 apfu, according to the substitution (i) ${ }^{M(1)} \mathrm{Me}^{2+}+{ }^{X(3)}(\mathrm{Sb} / \mathrm{As})^{3+}={ }^{M(1)} \mathrm{Cu}^{+}+{ }^{X(3)} \mathrm{Te}^{4+}$, where $\mathrm{Me}=\mathrm{Fe}, \mathrm{Zn}, \mathrm{Hg}$, etc. For Te contents between 2 and 4 apfu, the charge balance is maintained through the creation of vacancies at the $M(2)$ site, according to the substitution mechanism (ii) ${ }^{M(2)} \mathrm{Cu}^{+}+{ }^{X(3)}(\mathrm{Sb} / \mathrm{As})^{3+}={ }^{M(2)} \square+{ }^{X(3)} \mathrm{Te}^{4+}$ (e.g. Shimizu and Stanley, 1991). Summarising, the general chemical formula can be written as $\mathrm{Cu}_{10+x} \mathrm{Me}_{2-x}\left[(\mathrm{Sb} / \mathrm{As})_{4-x} \mathrm{Te}_{x}\right) \mathrm{S}_{13}$ for $0 \leq \mathrm{Te} \leq 2$ apfu and $\left(\mathrm{Cu}_{12-y} \square_{y}\right)\left[\mathrm{Te}_{2+y}(\mathrm{Sb} / \mathrm{As})_{2-y}\right] \mathrm{S}_{13}$ for $2<\mathrm{Te} \leq 4$ apfu. Data collected on the specimens from the Mohawk mine and the Prasolovskoe $\mathrm{Au}$ deposit agree with these substitution mechanisms. The relationship between formally monovalent cations $(\mathrm{Cu}+\mathrm{Ag})$ and $\mathrm{Te}$ is shown in Fig. 3a. There is a positive relationship up to $\sim 2 \mathrm{Te}$ apfu and $12(\mathrm{Cu}+\mathrm{Ag})$ apfu. Then, a negative correlation between the $\mathrm{Te}$ and $(\mathrm{Cu}+\mathrm{Ag})$ can be observed. This is probably related to the transition from substitution (i) to (ii). 
(a)

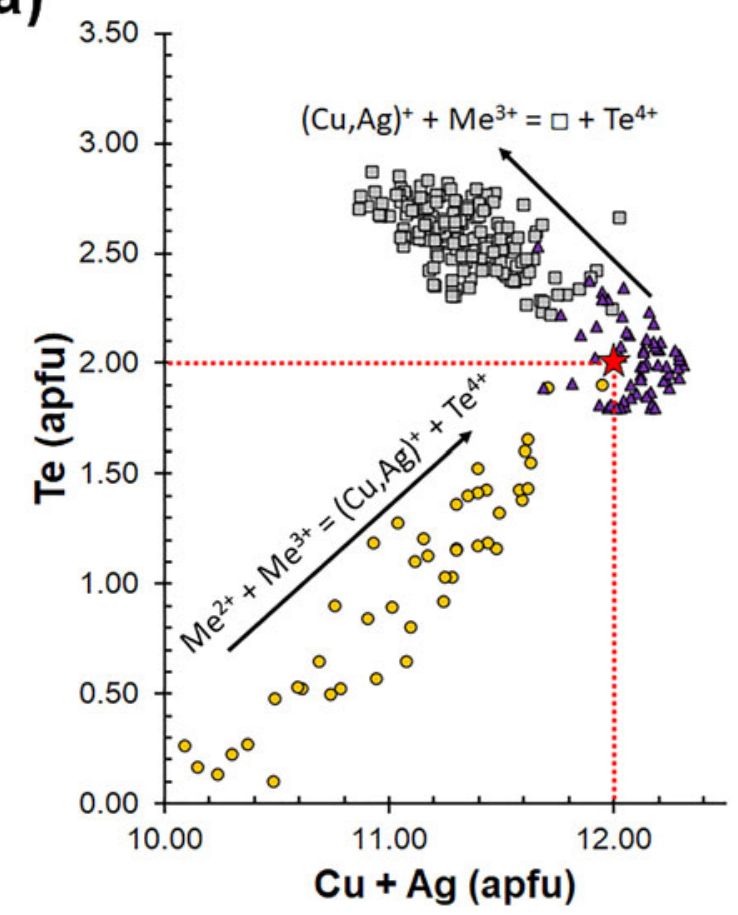

(b)

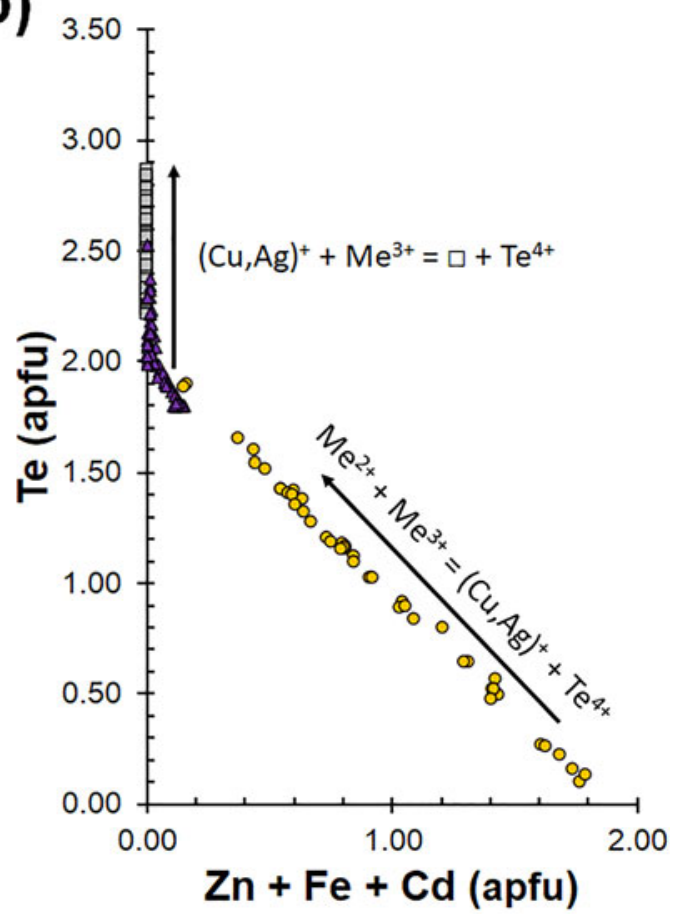

Fig. 3. Relationships between (a) Te vs. $(\mathrm{Cu}+\mathrm{Ag})$ and (b) Te vs. $(\mathrm{Zn}+\mathrm{Fe}+\mathrm{Cd})$ in apfu in stibiogoldfieldite. Symbols: violet triangles $=$ holotype specimen; grey squares = cotype specimen; orange circles = Prasolovskoe Au deposit. The red star indicates the position of the ideal stibiogoldfieldite, i.e. (Cu + Ag) $=12$ apfu and $\mathrm{Te}=2$ apfu.

This hypothesis is supported by Fig. 3b. Indeed, the content of $(\mathrm{Zn}+\mathrm{Fe}+\mathrm{Cd}+\ldots)$, i.e. formally divalent cations (Fe could also occurs as ferric iron when occurring in low amounts - e.g. Makovicky and Karup-Møller, 2017), decreases up to 2 Te apfu, when the sum of transition metals approaches zero. In the samples studied, the content of Te then increases up to $\sim 3$ apfu.

Taking the general formula discussed above, the holotype material has $x=2$, corresponding ideally to $\mathrm{Cu}_{12}\left[(\mathrm{Sb} / \mathrm{As})_{2} \mathrm{Te}_{2}\right]$ $\mathrm{S}_{13}$. Indeed, the amount of $\mathrm{Zn}$ and $\mathrm{Fe}$ is very low, close to the detection limit, i.e. 0.03(4) and 0.01(1), respectively, and the sum of the formally monovalent cations $\mathrm{Cu}$ and $\mathrm{Ag}$ is close to 12 apfu. Trivalent cations are represented by Sb (1.12 apfu), As (0.63 apfu) and minor Bi (0.22 apfu).

The chemical formula of cotype material has $\mathrm{Te}>2$ apfu, with $y \approx 0.6$, ideally $\left(\mathrm{Cu}_{11.4} \square_{0.6}\right)\left[\mathrm{Te}_{2.6}(\mathrm{Sb} / \mathrm{As})_{1.4}\right] \mathrm{S}_{13}$. This agrees with the empirical formula, showing $(\mathrm{Cu}+\mathrm{Ag})=11.33 \mathrm{apfu}$, with no formally divalent metals. Among trivalent cations, $\mathrm{Sb}$ is dominant over As ( 0.80 vs. $0.57 \mathrm{apfu})$, whereas the content of Bi (0.06 apfu) is negligible.

The composition of the sample from the Prasolovskoe $\mathrm{Au}$ deposit is more variable, ranging from tetrahedrite-( $\mathrm{Zn})$, with $\mathrm{As} /(\mathrm{As}+\mathrm{Sb})$ and $\mathrm{Te} /(\mathrm{As}+\mathrm{Sb}+\mathrm{Te})$ atomic ratios in the ranges $0.27-$ 0.44 and $0.02-0.23$, respectively, and stibiogoldfieldite, with the same ratios in the ranges $0.24-0.39$ and $0.26-0.47$. The wide compositional variability of tetrahedrite-group minerals from this Russian locality has been reported previously by Kemkina (2007).

\section{Miscibility gap along the stibiogoldfieldite-goldfieldite join}

Makovicky and Karup-Møller (2017) pointed out that along the join between synthetic $\mathrm{Cu}_{12}\left(\mathrm{Sb}_{2} \mathrm{Te}_{2}\right) \mathrm{S}_{13}$ and $\mathrm{Cu}_{10} \mathrm{Te}_{4} \mathrm{~S}_{13}$ a possible miscibility gap may occur between 3.5 and 2.1 Te apfu. Indeed, a charge with composition $\mathrm{Cu}_{10.62}\left(\mathrm{Sb}_{0.59} \mathrm{Te}_{3.44}\right) \mathrm{S}_{12.94}$ gave two unit-cells, i.e. $a=10.279$ and $10.330 \AA$. The same was observed for the charge compositions $\mathrm{Cu}_{11.37}\left(\mathrm{Sb}_{1.36} \mathrm{Te}_{2.65}\right) \mathrm{S}_{12.97}$ and $\mathrm{Cu}_{11.54}\left(\mathrm{Sb}_{1.51} \mathrm{Te}_{2.52}\right) \mathrm{S}_{12.93}$, whereas only one unit-cell was refined for the compositions $\mathrm{Cu}_{11.46}\left(\mathrm{Sb}_{1.58} \mathrm{Te}_{2.53}\right) \mathrm{S}_{12.96}$ and $\mathrm{Cu}_{11.93}\left(\mathrm{Sb}_{2.03} \mathrm{Te}_{2.00}\right) \mathrm{S}_{13.02}$. This was interpreted as due to the exsolution between Te-poor and Te-rich phases; such exsolutions were not observed in reflected light, suggesting the intimate nature of these intergrowths (Makovicky and Karup-Møller, 2017).

The refined unit-cell parameter of the holotype material, having the simplified composition $\mathrm{Cu}_{12}\left(\mathrm{Sb}_{1.1} \mathrm{As}_{0.7} \mathrm{Bi}_{0.2} \mathrm{Te}_{2.0}\right) \mathrm{S}_{13}$, is $a=10.347 \AA$, close to that given by Makovicky and Karup-Møller (2017) for Fe-free and Te-rich tetrahedrite, i.e. $a=10.352 \AA$. It is likely that the replacement of Sb by As, favouring a contraction of the unit-cell parameter, is balanced by the occurrence of $\mathrm{Bi}$, leading to an expansion of the unit-cell size. Indeed, the chemical composition of the holotype sample should be out of range of the hypothetical miscibility gap.

On the contrary, the cotype sample, ideally $\left(\mathrm{Cu}_{11.4} \square_{0.6}\right)$ $\left(\mathrm{Te}_{2.6} \mathrm{Sb}_{0.8} \mathrm{As}_{0.6}\right) \mathrm{S}_{13}$, is within the presumed miscibility gap, its chemistry closely corresponding to the charge with composition $\mathrm{Cu}_{11.37}\left(\mathrm{Sb}_{1.36} \mathrm{Te}_{2.65}\right) \mathrm{S}_{12.97}$. This charge gave two unit-cell parameters, $a=10.286$ and $10.344 \AA$. However, no exsolution phenomena nor intergrowths were observed on BSE images or in reflected light; moreover, PXRD patterns show no evidence for the occurrence of two tetrahedrite-like phases and only one unit-cell parameter, $a=10.304 \AA$, was refined. This discrepancy between synthetic and natural samples may be due to the occurrence of As replacing $\mathrm{Sb}$, in agreement with Makovicky and Karup-Møller (2017). 


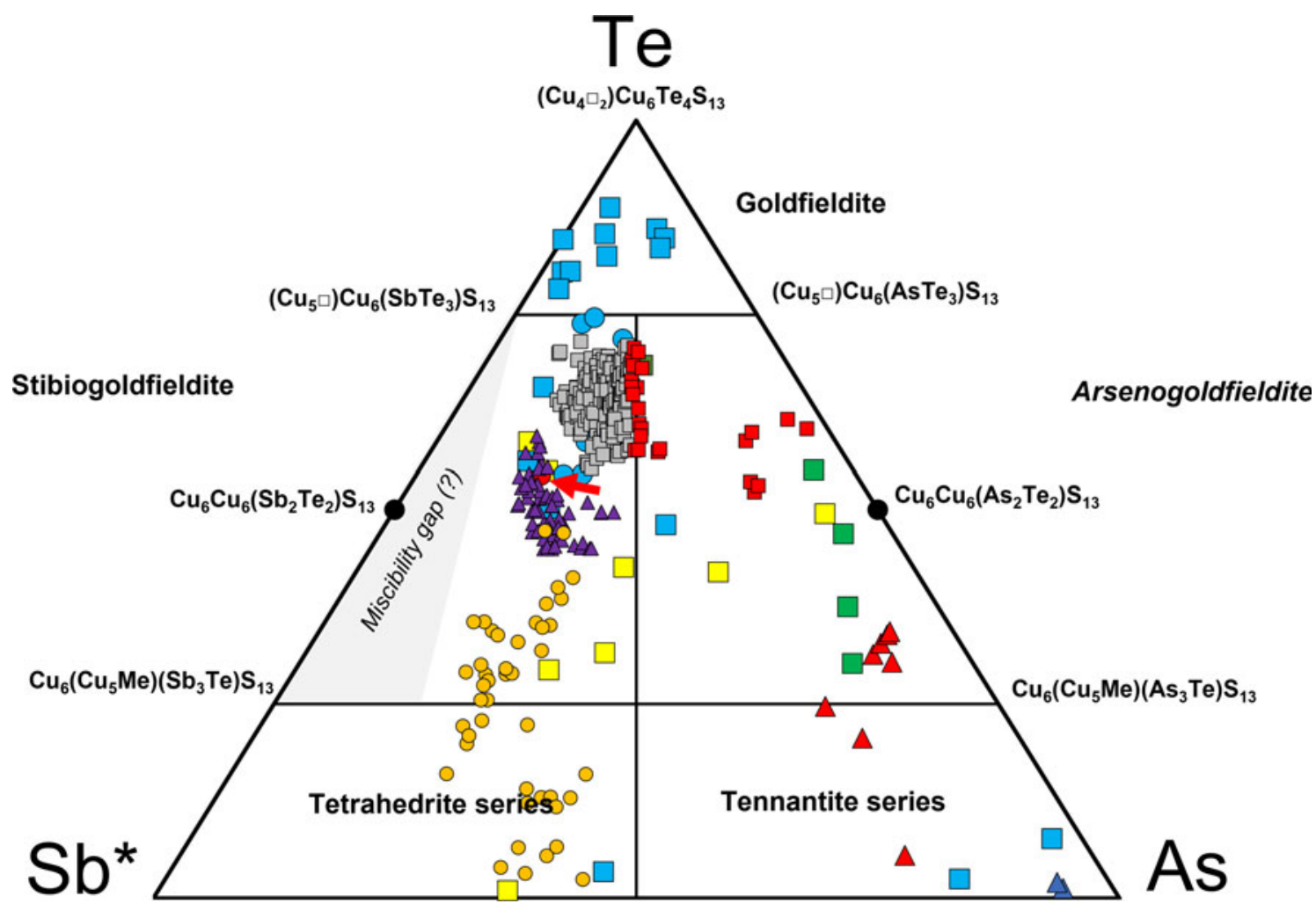

Fig. 4. Compositional variation of Te-bearing tetrahedrite-group minerals. For the samples studied in this work, the same symbols as in Fig. 3 are used. Selected chemical data from literature are shown. Symbols: red square = 'arsenogoldfieldite' associated with cotype stibiogoldfieldite; light blue circles = Ozernovskoe deposit, Kamchatka, Russia (Spiridonov et al., 2014); red circles=Goldfield, USA (Lévy, 1967 - also indicated by the red arrow); green squares = Marian Au mine, Philippines (Knittel, 1989); dark blue triangles = Sazare deposit, Japan (Kase, 1986); dark green square=Kawazu mine, Japan (Shimizu and Stanley, 1991); light blue squares = Rhodope area, southern Bulgaria - northern Greece (Repstock et al., 2016); yellow squares=Iriki mine, Japan (Shimizu and Stanley, 1991); red triangles = Ikadazu deposit, Japan (Kase, 1986). The light grey area indicates the possible miscibility gap. Sb* $=\mathrm{Sb}+\mathrm{Bi}$. Me $=$ formally divalent metals (e.g. $\mathrm{Cu}, \mathrm{Fe}, \mathrm{Hg}, \mathrm{Zn}, . .$.$) .$

The chemical variability of the samples as a function of the cations occurring in $X(3)$, along with selected literature data is shown in Fig. 4. Since minor Bi was considered along with $\mathrm{Sb}$ $\left(\mathrm{Sb}^{*}=\mathrm{Sb}+\mathrm{Bi}\right)$, some chemical data having As slightly dominant over $\mathrm{Sb}$ can be displaced towards the Sb field, due to the presence of some Bi. In particular, this occurs for some of the data for 'arsenogoldfieldite' associated with cotype stibiogoldfieldite. In the stibiogoldfieldite compositional field, available chemical data are always characterised by the coexistence of $\mathrm{Sb}$ and $\mathrm{As}$, whereas As-free or very As-poor compositions are not reported and could suggest the existence of a natural miscibility gap. On the contrary, in the compositional field of the not yet approved mineral species 'arsenogoldfieldite', compositions very poor in Sb have been reported; for instance, in the 'arsenogoldfieldite' observed in the cotype material in this work, Sb contents down to 0.06 apfu were measured. This could be related to the large misfit between pure stibiogoldfieldite and goldfieldite; such a misfit can be reduced through the partial replacement of Sb by As.

\section{Conclusions}

The investigation of Te-bearing members of the tetrahedrite group, following Biagioni et al. (2020), allowed the description of stibiogoldfieldite. Its formal approval by the IMA-CNMNC improves the classification of tetrahedrite-group minerals; moreover, the crystal-chemical investigations agree with previous investigations and hypotheses about the role of $\mathrm{Te}$ in these sulfosalts, as well as the mechanisms favouring its incorporation in their crystal structures (e.g. Makovicky and Karup-Møller, 2017).

Holotype stibiogoldfieldite corresponds to 'goldfieldite' originally described by Ransome (1909); consequently, although goldfieldite is still a valid mineral species, a study on natural specimens is mandatory, coupled with a definition of neotype material. As some occurrences of goldfieldite, with up to 3.77 Te apfu are known, their crystal-chemical study should be performed, refining our knowledge on this important sulfosalt group.

Acknowledgements. CB and MP acknowledge financial support from the Ministero dell'Istruzione, dell'Università e della Ricerca through the project PRIN 2017 "TEOREM - deciphering geological processes using Terrestrial and Extraterrestrial ORE Minerals", prot. 2017AK8C32. The study was also financially supported by the Ministry of Culture of the Czech Republic (longterm project DKRVO 2019-2023/1.II.c-d; National Museum, 00023272) for JS and ZD. The comments of Peter Leverett, Yves Moëlo, and an anonymous reviewer improved the original manuscript.

Supplementary material. To view supplementary material for this article, please visit https://doi.org/10.1180/mgm.2021.107

\section{References}

Andreasen J.W., Makovicky E., Lebech B. and Karup-Møller S. (2008) The role of iron in tetrahedrite and tennantite determined by Rietveld refinement of neutron powder diffraction data. Physics and Chemistry of Minerals, 35, $447-454$. 
Ashley R.P. (1974) Goldfield mining district. Pp. 49-66 in: Guidebook to the Geology of Four Tertiary Volcanic Centers in Central Nevada. Bureau of Mines and Geology Report, 19.

Biagioni C., George L.L., Cook N.J., Makovicky E., Moëlo Y., Pasero M., Sejkora J., Stanley C.J., Welch M.D. and Bosi F. (2020) The tetrahedrite group: Nomenclature and classification. American Mineralogist, 105, 109-122.

Biagioni C., Sejkora J., Musetti S., Makovicky E., Pagano R., Pasero M. and Dolníček Z. (2021) Stibiogoldfieldite, IMA 2020-104. CNMNC Newsletter 61; Mineralogical Magazine, 85, https://doi.org/10.1180/mgm.2021.48

Brese N.E. and O'Keeffe M. (1991) Bond-valence parameters for solids. Acta Crystallographica, B47, 192-197.

Bruker AXS Inc. (2016) APEX 3. Bruker Advanced X-ray Solutions, Madison, Wisconsin, USA.

Burnham C.W. (1962) Lattice constant refinement. Carnegie Institute Washington Yearbook, 61, 132-135.

Criddle A.J. and Stanley C.J. (1993) Quantitative data file for ore minerals, $3^{\text {rd }}$ edition. Chapman \& Hall, London.

Dmitrieva M.T., Yefremov V.A. and Kovalenker V.A. (1987) Crystal structure of As-goldfieldite. Doklady Akademii Nauk SSSR, Earth Science Section, 297, 141-144.

Flack H.D. (1983) On enantiomorph-polarity estimation. Acta Crystallographica, A39, 876-881.

Hall S.R. (1975) Crystal structures of the chalcopyrite series. The Canadian Mineralogist, 40, 699-710.

Holland T.J.B. and Redfern S.A.T. (1997) Unit cell refinement from powder diffraction data: the use of regression diagnostics. Mineralogical Magazine, 61, 65-77.

Johnson M.L. and Burnham C.W. (1985) Crystal structure refinement of an arsenic-bearing argentian tetrahedrite. American Mineralogist, 70, 165-170.

Johnson N.E., Craig J.R. and Rimstidt J.D. (1988) Crystal chemistry of tetrahedrite. American Mineralogist, 73, 389-397.

Kalbskopf R. (1974) Synthese und Kristallstruktur von $\mathrm{Cu}_{12-\mathrm{x}} \mathrm{Te}_{4} \mathrm{~S}_{13}$, dem Tellur-Endglied der Fahlerze. Tschermaks Mineralogische und Petrographische Mitteilungen, 21, 1-10.

Kase K. (1986) Tellurian tennantite from the Besshi-type deposits in Sambagawa metamorphic belt, Japan. The Canadian Mineralogist, 24, 399-404.

Kato A. and Sakurai K. (1970) Re-definition of goldfieldite $\mathrm{Cu}_{12}(\mathrm{Te}, \mathrm{As}, \mathrm{Sb})_{4} \mathrm{~S}_{13}$. Journal of the Mineralogical Society of Japan, 10, 122 [in Japanese].

Kemkina R.A. (2007) Fahlores of the Prasolovka Au-Ag volcanogenic deposit, Kunashir Island, Russian Far East. Russian Journal of Pacific Geology, 1, 130-143.

Knittel U. (1989) Composition and association of arsenian goldfieldite from the Marian Gold Deposit, Northern Luzon, Philippines. Mineralogy and Petrology, 40, 145-154.

Kovalenker V.A. and Plotinskaya O.Yu. (2005) Te and Se mineralogy of Ozernovskoe and Prasolovskoe epithermal gold deposits, Kuril Kamchatka volcanic belt. Geochemistry, Mineralogy and Petrology, 43, 118-123.

Kovalenker V.A., Nekrasov I.Y., Sandormiskaya S.M., Nekrasova A.N., Malov V.S., Danchenko V.Ya. and Dmitrieva M.T. (1989) Sulfide-selenide-telluride mineralization of epithermal mineral occurrences of the Kuril-Kamchatka volcanic belt. Mineralogiceskij Zhurnal, 11, 3-18 [in Russian].

Kraus W. and Nolze G. (1996) POWDER CELL - a program for the representation and manipulation of crystal structures and calculation of the resulting X-ray powder patterns. Journal of Applied Crystallography, 29, 301-303.

Lévy C. (1967) Contribution à la minéralogie des sulfures de cuivre du type $\mathrm{Cu}_{3} \mathrm{XS}_{4}$. Mémoires du Bureau de Recherches Géologiques et Minières, 54 $1-178$.
Makovicky E. and Karup-Møller S. (2017) Exploratory studies of substitutions in the tetrahedrite/tennantite-goldfieldite solid solution. The Canadian Mineralogist, 55, 233-244.

Moëlo Y., Makovicky E., Mozgova N.N., Jambor J.L., Cook N., Pring A., Paar W.H., Nickel E.H., Graeser S., Karup-Møller S., Balić-Žunić T., Mumme W.G., Vurro F., Topa D., Bindi L., Bente K. and Shimizu M. (2008) Sulfosalt systematics: a review. Report of the sulfosalt sub-committee of the IMA Commission on Ore Mineralogy. European Journal of Mineralogy, 20, 7-46.

Novgorodova M.I., Tsepin A.I. and Dmitrieyeva M.T. (1978) The new isomorphous series in grey ore group. Zapiski Vserossijskogo Mineralogicheskogo Obschchestva, 107, 100-110 [in Russian].

Ondruš P. (1993) A computer program for analysis of X-ray powder diffraction patterns. Materials Science Forum, 133-136, 297-300.

Pohl D., Ließmann W. and Okrugin V.M. (1996) Rietveld analysis of selenium-bearing goldfieldites. Neues Jahrbuch für Mineralogie, Monatshefte, 1996, 1-8.

Pouchou J.L., and Pichoir F. (1985) "PAP" (jpZ) procedure for improved quantitative microanalysis. Pp. 104-106 in: Microbeam Analysis (J.T. Armstrong, editor). San Francisco Press, San Francisco.

Ransome F.L. (1909) Geology and ore deposits of Goldfield, Nevada. U.S. Geological Survey, Professional Papers, 66.

Repstock A., Voudouris P., Zeug M., Melfos V., Zhai M., Li H., Kartal T. and Matuszczak J. (2016) Chemical composition and varieties of fahlore-group minerals from Oligocene mineralization in the Rhodope area, Southern Bulgaria and Northern Greece. Mineralogy and Petrology, 110, 103-123.

Rockwell B.W. (2000) The Goldfield Mining District, Nevada: An Acid-Sulfate Bonanza Gold Deposit. In: Guidebook for Field Trip to the Basin and Range (F.F. Sabins, editor). 14th International Conference for Applied Geologic Remote Sensing, Las Vegas, Nevada, USA, November 6-8, 2000.

Sharwood W.J. (1907) Gold tellurides. Mining and Scientific Press, 94, 731-732.

Sheldrick G.M. (2015) Crystal Structure Refinement with SHELXL. Acta Crystallographica, C71, 3-8.

Shimizu M. and Stanley C.J. (1991) Coupled substitution in goldfielditetetrahedrite minerals from the Iriki mine, Japan. Mineralogical Magazine, 55, 515-519.

Spiridonov E.M., Ivanova Yu.N. and Yapaskurt V.O. (2014) Selenium-bearing goldfieldite and fischesserite $\mathrm{AuAg}_{3} \mathrm{Se}_{2}$ - petzite $\mathrm{AuAg}_{3} \mathrm{Te}_{2}$ solid solutions in ores from the Ozernovskoe volcanogenic deposit (Kamchatka). Doklady Earth Science, 458, 1139-1142.

Thompson R.M. (1946) Goldfieldite-tellurian tetrahedrite. University of Toronto Studies, Geological Series, 50, 77-78.

Tolman C.F. and Ambrose J.W. (1934) The rich ores of Goldfield, Nevada. Economic Geology, 29, 255-279.

Trudu A.G. and Knittel U. (1998) Crystallography, mineral chemistry and chemical nomenclature of goldfieldite, the tellurian member of the tetrahedrite solid-solution series. The Canadian Mineralogist, 36, 1115-1137.

Wedepohl K.H. (1995) The composition of continental crust. Geochimica et Cosmochimica Acta, 59, 1217-1232.

Welch M.D., Stanley C.J., Spratt J. and Mills S.J. (2018) Rozhdestvenskayaite $\mathrm{Ag}_{10} \mathrm{Zn}_{2} \mathrm{Sb}_{4} \mathrm{~S}_{13}$ and argentotetrahedrite $\mathrm{Ag}_{6} \mathrm{Cu}_{4}\left(\mathrm{Fe}^{2+}, \mathrm{Zn}_{2} \mathrm{Sb}_{4} \mathrm{~S}_{13}\right.$ : two Ag-dominant members of the tetrahedrite group. European Journal of Mineralogy, 30, 1163-1172.

Wilson A.J.C. (1992) International Tables for Crystallography. Volume C. Kluwer, Dordrecht, The Netherlands.

Wuensch B.J. (1964) The crystal structure of tetrahedrite, $\mathrm{Cu}_{12} \mathrm{Sb}_{4} \mathrm{~S}_{13}$. Zeitschrift für Kristallographie, 119, 437-453.

Wuensch B.J., Takéuchi Y. and Nowacki W. (1966) Refinement of the crystal structure of binnite, $\mathrm{Cu}_{12} \mathrm{As}_{4} \mathrm{~S}_{13}$. Zeitschrift für Kristallographie, 123, 1-20. 